\title{
Unit Cost Comparison Method Using Activity-Based Costing of Appendectomy against INA-CBG's Rates in Bhayangkara Hospital Medan 2018
}

\author{
Jimy Fran ${ }^{1}$, Destanul Aulia ${ }^{2}$, Juanita Juanita ${ }^{2}$ \\ ${ }^{1}$ Department of Hospital Administration Faculty of Public Health, University of North Sumatra, \\ Indonesia \\ 2Department of Health Administration and Policy, School of Public Health University of North Sumatra, \\ Indonesia \\ Email: jimyfran1995@gmail.com
}

\begin{abstract}
:
Determination of tariffs with traditional methods is considered unable to overcome various difficulties in determining rates in hospitals. Activity-Based Costing (ABC) is one method of calculating rates that are considered efficient. The purpose of this study was to determine the ratio of unit cost to INA-CBG's rates in class III acute appendicitis patients at Bhayangkara Medan Secondary Hospital in 2018. This study is a quantitative descriptive study using the ABC method, where this study calculates the unit cost of acute appendicitis. Samples were taken based on total sampling technique, that is, all patients with class III acute appendicitis in Bhayangkara Hospital Medan. Data was collected using primary data in the form of direct interviews from the field and secondary data in the form of patient medical records, as well as costs incurred from all activities that happened. Analysis of the data used in this study is a non-statistical quantitative analysis test. The results of the study show that the unit cost is smaller than the INA-CBG's rate with a difference of Rp. 1,699,448.00. It is recommended that the Head of the Bhayangakara Level II Hospital in Medan analyze the unit cost of each disease using the ABC method in order to have efficient tariffs. Keywords:

Appendicitis; $A B C$; unit cost; rates INA-CBG's
\end{abstract}

\section{Introduction}

Hospital is a health care institution that organizes personal health services in plenary that provides inpatient, outpatient, and emergency. The essential nature of the hospital is meeting the needs and demands of patients who expect the completion of his health problems at the hospital. Patients perceive that only hospitals able to provide medical services as healing and recovery efforts for the pain he suffered. Patient care is hoping ready, fast, responsive, and comfortable to complaints disease patients (Listiyono, 2015).

BPJS (Social Insurance Administration Organization) program implemented at the hospital wearing a case-mix system INA-CBG's (Indonesia Case-Based Groups). The so-called case-mix system is a grouping of diagnoses and procedures concerning the clinical characteristics that are similar/same, and maintenance costs are similar / the same, the grouping has done by using grouper. There are three essential components in the case-mix system, namely: ICD (International Classification of Disease) 10 for coding diagnoses, ICD 9 to procedural actions taken, and the group fee (Ministry of Health, 2014).

The rapid development of information technology coupled with the increasingly fierce global competition requires all types of companies, including hospitals, to manage their companies. Determination of tariffs with traditional methods is considered unable to overcome various difficulties in determining rates in hospitals. According to Mulyadi (2014), there are 
several cost analysis methods developed, namely: simple distribution, step down method, a binary distribution, multiple distributions, activity-based costing, and original cost method.

There are three developments that hospitals can adopt in order to continue to have competitive advantages over other health care providers, namely increasing cost-effectiveness without reducing service quality, having data and information flows that help in optimizing resources, and creating new choices in improving service quality. Activity-based costing (ABC) is one of the alternative methods that surround the three developments. $\mathrm{ABC}$ method is a method that uses activities as a basis for classifying costs to determine rates. ABC method imposes activity cost on products or services based on consumption used to provide more accurate tariff information (Islahuzzaman, 2014).

Acute appendicitis is the most frequent surgical problem, and an appendectomy is one of the most frequent emergency operations worldwide. Limitation of acute appendicitis is acute appendicitis that requires surgical intervention, usually has a duration of no more than 48 hours (Craig, 2014). Acute appendicitis will later become perforated appendicitis and cause $67 \%$ of deaths in cases that occur (Paudel et al ., 2010).

According to the World Health Organization (WHO) in 2004, it was found that appendicitis affects 418 million people worldwide, 259 million of whom are male and the rest are women, and reach a total of 118 million in the Southeast Asia region. In America, the survey results report the incidence of appendicitis, where there are 11 cases of appendicitis in every 1000 people (Dahmardehei, 2013). Also, according to the Indonesian Ministry of Health in 2009, appendicitis was included in the list of the ten most diseases in hospitalized patients in various regions of Indonesia with a total incidence of 30,703 cases and 234 people who died from this disease.

Based on the results of the preliminary survey obtained 30 patients hospitalized appendicitis is JKN participants in 2018 whose claims have been calculated using the INA-CBG's package by division: class I as many as ten people, class II as many as 13 people, and class III as many as 13 people. In addition to these data, we also know the information that there were 2370 patients who were hospitalized with the highest distribution of patients in Internal Medicine, Obstetrics, and Surgery 2018.

Based on the results of the discussion together with the administrative section of Bhayangkara Hospital Medan, complaints shows that the hospital spent a high cost to treat appendicitis patients. The hospital acknowledged that this was very detrimental because it was not following the claims received from the BPJS.

From the results of the above explanation, the high incidence of appendicitis and costs incurred hospital for the disease of the results of a preliminary survey is a serious health problem that researchers interested in researching with the title Comparison of Unit Cost Appendectomy Using the ABC Method Against INA-CBG's rate Bhayangkara Hospital Medan 2018.

The problem of this research is that the comparison of unit cost appendectomy has not been known using the ABC method to the INA-CBG's rates at the Bhayangkara Hospital Medan in 2018.

The purpose of this study was to determine the ratio of unit costs to the rates of INACBG's appendicitis in the Bhayangkara Hospital Medan in 2018. 
The results of this study can be input for the hospital management in determining policies relating to the efficiency of health costs incurred for the service of inpatient appendicitis patients. It can be input into evaluations to determine health financing claims, especially surgical disease for the government and BPJS. For the general public, this research is expected to be a reference for INA-CBG's system.

\section{Research Methods}

This type of research is descriptive quantitative research. This study was to analyze the efficiency of the appendectomy in the form of unit cost, the real cost and INA-CBG's rates for JKN patients with acute appendicitis and perforated appendicitis at the Bhayangkara Hospital in Medan using the Activity Based Costing method.

The subjects of this study were all related to the appendectomy service. The object of this research is all activities and costs that occur in the appendectomy service at Bhayangkara Hospital in Medan. The population in this study is all data and case files of patients with acute appendicitis and perforated appendicitis who use BPJS Health at Bhayangkara Hospital in Medan. The sample is taken based on the Purposive Sampling technique, where the researcher determines the sampling by setting inclusion and exclusion criteria following the research objectives so that it is expected to answer the research problems.

The research instruments used were primary data and secondary data. Primary data is data obtained from interviews directly from the field. Secondary data is data obtained from search documents in the form of patient medical records, as well as costs incurred from all activities that occur.

The data analysis method used in this study is a non-statistical quantitative analysis technique. Data in the form of numbers are analyzed using the theory of ABC (Activity Based Costing). The steps for calculating the unit cost using the $\mathrm{ABC}$ method are as follows:

1. Identify activities that are cost objects

2. Identify direct costs

3. Identify overhead costs

4. Calculate direct and indirect costs (overhead)

5. Calculate the total cost of the product by adding all direct and indirect costs.

After getting the unit cost calculation, compared it with the total claim rate of INACBG's, so that it can be known if there is a difference in the total tariff between the unit cost and the INA-CBG's tariff.

\section{Discussion}

Bhayangkara Hospital Medan is a class B police hospital in North Sumatra that receives appendectomy services in appendicitis patients with JKN participants. This hospital has quite complete facilities, such as:

Table 1. Treatment Room/Class Facilities at Bhayangkara Hospital Medan in 2019

\begin{tabular}{clc}
\hline No. & Classroom & Number of TT \\
\hline 1. & Super VIP & 2 \\
2. & VIP & 7 \\
3. & class I & 9
\end{tabular}




\begin{tabular}{llc} 
4. & class II & 11 \\
5. & class III & 16 \\
6. & ICU & 6 \\
7. & Perinatology & 5 \\
8. & Insulation & 4 \\
9. & Custody & 33 \\
\hline & Total & 93 \\
\hline
\end{tabular}

Bhayangkara Hospital Medan has excellent services such as a) Integrated Service Center, is a place for complaints and protection for victims of acts of violence against children and women. b) VCT / CST Clinic is an information center for counseling services, testing, and treatment of HIV infections. c) Laboratories, serving patients within 24 hours, serving general check-ups: hepatitis, kidney diabetes, drug screening, and HIV. d) Mortuary / forensic room, carrying out task support for police operations.

The number of types of personnel in Bhayangkara Medan Hospital In 2019, as many as 116 organic personnel, as many as 26 partners medical personnel, $138 \mathrm{PK}$ personnel, with a total number of 280 personnel. Staff who carry out health services at Bhayangkara Medan Hospital, as in the following table:

Table 2. Distribution Type Power at Bhayangkara Hospital Medan

\begin{tabular}{clccc}
\hline No. & Personnel & $\mathbf{2 0 1 7}$ & $\mathbf{2 0 1 8}$ & $\mathbf{2 0 1 9}$ \\
\hline 1 & organic & 95 & 112 & 116 \\
2 & physician Partners & 20 & 24 & 26 \\
3 & PK & 123 & 138 & 138 \\
\hline & total & 238 & 274 & 280 \\
\hline
\end{tabular}

\subsection{Stages in the calculation of Activity Based Costing (ABC)}

Steps for determining tariffs for patients in service companies such as the Bhayangkara Hospital Medan, in general, are carried out through two stages, namely identification of costs and charges. The initial steps taken by the action include identification and classification of activity costs, classification of cost activities (Unit Activity Cost Levels, Batch Related Activity Cost, Product Sustaining Activity Cost and Facility Sustaining Activity Cost), identification of cost drivers and determination of the cost per unit cost driver. The next step is to charge activity costs to each product using the cost driver.

\subsection{Identification and Classification of Activities Fee}

The activities contained in each inpatient unit of Bhayangkara Medan Hospital consist of maintenance action costs, administrative costs, patient consumption costs, maintenance material costs, building depreciation costs, and facility depreciation costs. The supporting data needed to identify the costs of each element of activity during 2018 is shown in the following table:

Table 3. Costs per Element of Activities in ED, Surgery Rooms and Class III Nursing Rooms Cases of Appendicitis Bhayangkara Hospital Medan

\begin{tabular}{cll}
\hline No. & Elements of Cost & Total (USD) \\
\hline 1. & Health Worker Fee & 677989303 \\
2. & Administrative costs & 252840565 \\
3. & Cost of maintaining an inpatient room & 316050000 \\
4. & Costs of Materials Consumable & 195107328 \\
5. & Depreciation Costs of Building & $38,006,425$
\end{tabular}


Additional supporting data required in the identification and classification of costs using the $\mathrm{ABC}$ method is the number of inpatients for one year. The room that is the reference is the three rooms that become the place of care and the provision of appendicitis case actions with details, as shown in the table:

Table 4. Number of Hospitalized Patients at Bhayangkara Medan Hospital in 2018

\begin{tabular}{clccc}
\hline No. & Nursing Room & Number of Patients & Average per month \\
\hline 1. & Accident and & emergency & 3246 & 108 \\
2. & department & Surgical room & 606 & 20 \\
3. & class III & 550 & 18 \\
\hline
\end{tabular}

\subsection{Unit Cost Calculations Using the ABC Method in Appendectomy Cases}

Based on table 5 , the calculation of the unit cost of appendectomy after being calculated is Rp. 2,107,252. The number of unit costs for appendectomy cases, calculated based on the direct cost of the cost object consists of labor, cost of consumables and consumption costs with the cost driver is the number of days of care, number of patients and floor area. The cost of consumables includes all costs related to the direct operation of activities at the unit level in this emergency unit, inpatient room and operating room (OK). Labor costs include the costs of doctors, nurses, administration and cleaning services, and overhead costs (indirect costs in the form of facility maintenance, building depreciation, and operations) as other costs calculated in determining unit costs.

\subsection{Comparison of Unit Cost with the Rates of INA-CBG's in Appendectomy Case

\begin{tabular}{lll}
\hline Case & unit Cost & INA CBG's \\
\hline Appendectomy & Rp. 2.107 .252 & Rp. 3.806 .700 \\
\hline
\end{tabular}

Based on the table above, we can see that in the case of appendectomy unit cost is Rp. 2,107,252 it is lower than INA-CBG's which is Rp.3,806,700.00 with a difference in cost of Rp. $1,699,448$. The tariff calculation at INA-CBG's uses a tool in the form of software that has been determined by the Ministry of Health, so that the output rates are following the established database.

However, human error can occur in all cases, but for this study, it can be ascertained its accuracy because only one diagnosis is used. The accuracy of the diagnosis and procedure coding will affect the accuracy of the rates at INA-CBG's. Thus the difference will also be affected by the accuracy of the coding.

This is raised because of the recapitulation of data between the real rates and the

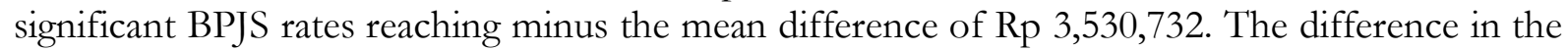
hospital is overcome by cross-subsidizing patients from other parts of the surplus. It is usually subsidized from medical sections where the medical department rarely uses actions, so the hospital can cope with and subsidize the positive tariff difference. Patients who use surgical procedures, on average, suffer losses because INA-CBG's rates are insufficient to be juxtaposed with the real rates, which are general patient rates. 
Table 5. Grouping Costs and Cost Drivers Apendiktomi at Level II Police Hospitals Medan in 2018

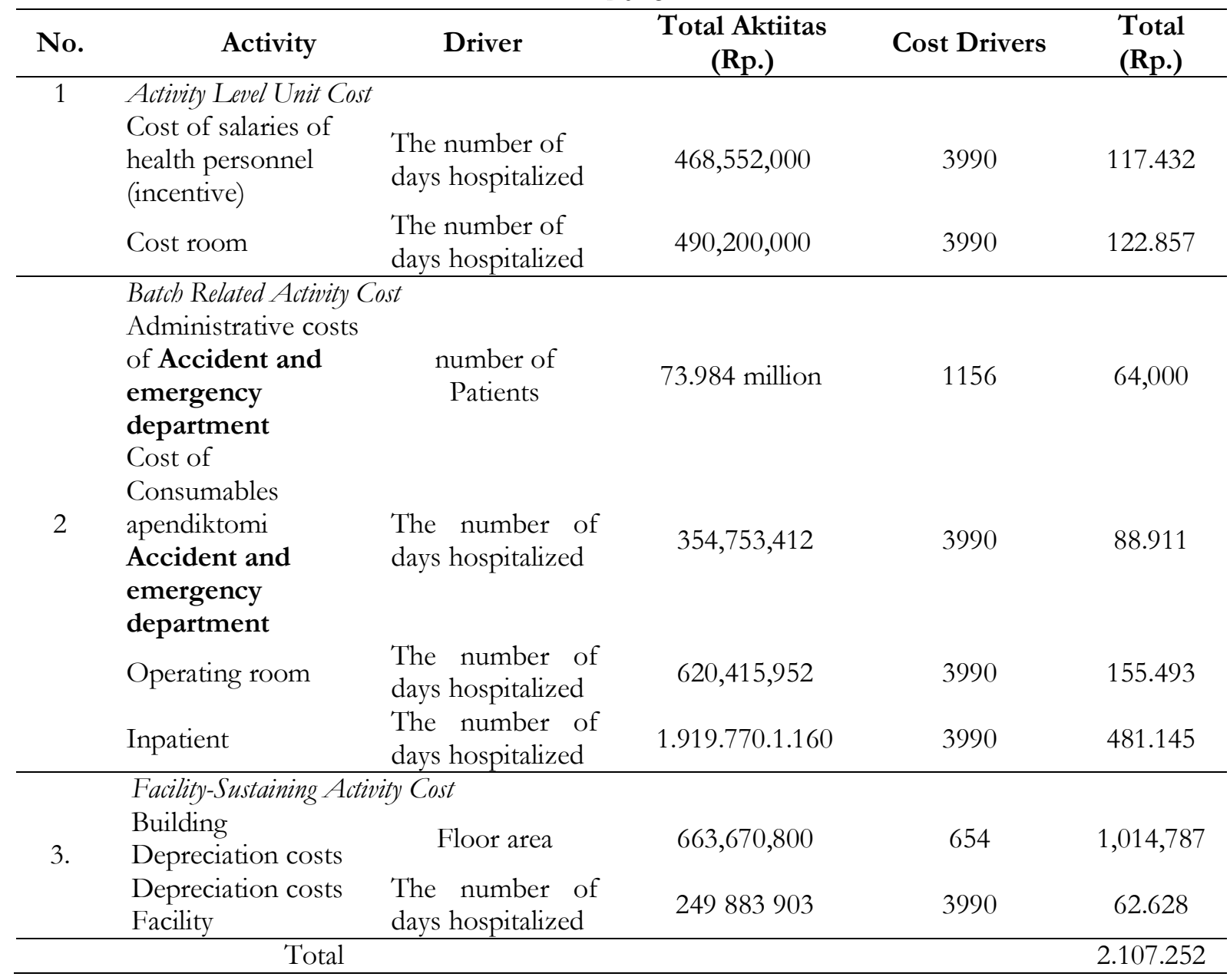

Rahayu (2012), in his publication entitled "Application of Activity Based Costing Method in Determining the Amount of Inpatient Service Rates at West Kalimantan Bhayangkara Hospital" concluded that the calculation using ABC method resulted in more accurate costs because it uses various cost drivers and costs of costs overhead. So far, tariff determination using conventional methods has caused undercosting and overcosting products.

Differences in unit cost with INA-CBG's rates BPJS patients hospitalized appendectomy cases at Medan Bhayangkara Hospital are also supported by drug rates used by patients during treatment. The longer the patient is treated, the need for the medication used will increase. The age group of patients can influence drug rates. Unlike the age of the patient, the dosage of the drug used will also be different, so that it will affect the amount of the tariffs incurred.

\section{Conclusion}

Comparison of unit costs against the rates of INA-CBG's appendectomy cases at Bhayangkara Hospital in Medan shows that the real costs of hospitals are greater than the rates of INA-CBG's. There is a difference in calculation costs using the INA-CBG's rate and the ABC method, which is Rp. 1,699,448.

The difference in value above is influenced by the INA-CBG's rates, which have been added to the profits so that the amount is greater. For details of the INA-CBG's tariff, it cannot 
be explained because it is in the form of a package per 1 diagnosis.

It is expected that the Medan Bhayangkara Hospital can use the ABC method to analyze unit costs for each disease in the hospital in order to have a more efficient tariff and certainly can improve patient satisfaction.

\section{References}

Amrizal, MN. (2009). Training Case-Mix-CBG's INA. Bandung.

Basirun et al. (2012). Difference Analysis Based Financing Rates INA-CBG's Version 3.0 Compared with the Real Hospital Rates in Patients with schizophrenia Case JAMKESMAS Hebefrenik Inpatient mental hospital 2012. Radjiman Wedodiningrat Semarang.

Craig, Sandy. (2014). Appendicitis. http://emedicine.medscape.com/article/773895overviewa0156, October 12th, 2014.

Dahmardehei, M. et al. (2013). Diagnostic Value of leukocytosis, ESR, CRP in Patients with Suspected Acute Appendicitis. Zahedan Journal of Research in Medical Science, May, 59.

Ministry of Health. Academic Paper 2004 Act of the National Social Security System (Navigation), Jakarta.

Ministry of Health. (2008). Use case-mix System To Press Health Costs, Jakarta.

Ministry of Health. (2010). The Health Profile of Indonesia 2009, Jakarta.

Dumaris, Hotma. (2018). Analysis of Differences in Rates Hospitals and Rates INA-CBG's Outpatient Services in Budhi Asih Hospital Jakarta 2015, Jakarta.

Hidayat, AM, et al. (2016). Unit Cost Analysis Method Using Activity Based Costing, Yogyakarta.

Horngren, CT, Datar, Srikant, M., Foster, \& George. (2006). Cost accounting a managerial emphasis (12th Edition). New York, USA: Prentice-Hall.

Listiyono, RA. (2015). Descriptive Study About the Quality of Service in the General Hospital Dr. Wahidin Sudiro Husodo Mojokerto Post Type B. Being Hospital Surabaya.

Ministry of Health. (2014) Ministry of Health Regulation No. 27 of 2014 on the System INACBG's.

Ministry of Health. (2016) Ministry of Health Regulation No. 52 of 2016 on the Standard Rates of Health Services in the Implementation of Health Insurance Program.

Mulyadi. (2014). Activity-based cost system (Edition 7, pp. 47-53). Yogyakarta: UPP STIM YKPN.

Paudel GR., Et al. (2010). Conservative Treatment in Acute Appendicitis, Department of Surgery, Department of Dermatology and Clinical Epidemiology Unit, BP Kairala Institute of Health Sciences, Dharan, Nepal. Vol.50, No.4, Issue 180.

Rahayu, S. (2012). Application of Activity Based Costing Method in Determining Rates Besaranya Inpatient Services at West Kalimantan Police Police Hospitals. Journal of Auditing and Accounting Faculty of Economics. 1 (1), 9-10. 